\title{
Occupational skin diseases and prevention among sanitation workers in China
}

\author{
Yuehua Yan ${ }^{1}$, Xinggang Wang ${ }^{2}$, Jianbo Wu ${ }^{1}, \mathrm{Li} \mathrm{Xu}^{1}$
}

1. Department of Dermatology, Zhongnan Hospital of Wuhan University

2. Department of Dermatology, Zibo Prevention and Treatment Center for

Occupational Diseases

\begin{abstract} research are also insufficient in developing countries like China.

DOI: http://dx.doi.org/10.4314/ahs.v15i3.10 2015;15(3):768-75. doi: http://dx.doi.org/10.4314/abs.v15i3.10

\section{Introduction}

In recent decades, urbanization has become a widespread trend in developing countries with rapid economic development. As a result of urbanization, the large population concentrated in cities has caused many sanitation problems, including a lot of garbage, dirty streets and blocked drains ${ }^{1}$ which greatly increase the sanitation workers' workload and working hours.
\end{abstract}

Background: Little research has been focused on the health status or the occupational protection awareness of sanitation workers. The policy recommendations on the occupational safety and health of sanitation workers based on the scientific

Objective: To study the incidence of dermatoses and the relevance with occupational exposure, protection awareness and protective measures among sanitation workers for better management and protection of the sanitation workers.

Methods: 273 sanitation workers and 113 administrative staff from 11 streets of Wuhan were recruited. Dermatological problems were evaluated and recorded by physical examination. Occupational exposure, protection awareness, the use of protective equipments and personal history of skin disease were assessed by questionnaires.

Results: Compared with administrative staff, sanitation workers had much more occupational dermatological problems and had a much higher rate of harmful ultraviolet ray exposure. Young sanitation workers were more aware of occupational self-protection and a relatively higher rate of them using protective equipments compared with old ones.

Conclusion: Exposure to multiple health hazards and the poor use of protective equipments are related to skin diseases in sanitation workers. Prejob training of self-protection and the use of protective equipments are recommended.

Keywords: sanitation worker; occupational skin disease; protection awareness; protective measures

Cite as: Yan Y, Wang X, Wu J, Xu Li. Occupational skin diseases and prevention among sanitation workers in China. Afri Health Sci.

Sanitation workers are responsible for cleanliness maintenance of the environment. In developing countries, such as China, with limited resources most of the clean-
Corresponding author:
Yuehua Yan,
No. 169 Donghu Road,
Wuchang District, Wuhan,
Hubei Province, China. 430072.
Telephone: +86-027-67812888
Fax: +86-027-67812892
Email: yanyueh678@163.com

ing process in urban localities remains manual. With improper classification of waste materials at the source, all types of garbage are being disposed on the streets. Sanitation workers are exposed to dirt, infective organisms, and other hazardous materials like chemicals, animal excreta and sharp objects. As working in the open air, sanitation workers are also suffered from rain, snow, sand, cold and ultraviolet rays. These factors lead to harmful effects on the overall health of the sanitation workers, including $\operatorname{skin}^{2}$, hair ${ }^{3}$, respiratory ${ }^{4}$, gastrointestinal ${ }^{5}$, urogenital $^{2}$, as well as orthopedic problems ${ }^{6}$.

Skin serves as a natural barrier from pathogens and damage between the internal and external environment in body defense, and is predisposed to disease when subjected to environmental stressors. Sanitation workers are especially prone to a range of dermatological problems considering their occupation ${ }^{2}$, however little research has been focused on the skin exposure, the protective measures and the occurrence of dermatoses among sanitation workers. One of the most important factors that affects the use of protective measures is occupation disease prevention awareness ${ }^{7,8}$. But few reports mentioned the detailed survey of sanitation workers' awareness of self-protection and protective measures. 
The aim of this was to study the incidence of dermatoses and its relevance with occupational exposure, protection awareness and protective measures among sanitation workers in Wuhan (China) for better management and protection of the sanitation workers in developing countries like China. A random sampling study was conducted and 273 sanitation workers and $113 \mathrm{ad}-$ ministrative staff were recruited from 11 streets of $\mathrm{Wu}$ han, a capital city of central China, from March 2011 to March 2012. The investigation included a general physical examination about dermatoses and a questionnaire survey for occupational exposure, environmental hazards, protection awareness, the use of protective equipments, personal history of skin disease and health complaints.

\section{Methods}

\section{Study subjects}

The study was a descriptive, register-based survey carried out by face-to-face interviews on the streets in Wuhan between March 2011 and March 2012. 11 streets were randomly selected in Wuchang district of congested area in Wuhan, China. A total of 273 sanitation workers and 113 administrative staff completed the survey. The sanitation workers were randomly selected from the streets and the administrative staff were also randomly selected and all worked in the sanitation office. The occurrence of dermatoses in each participant was evaluated by physical examination. Occupational exposure, environmental hazards, use of protective equipments, history of skin disease and health complaints were assessed by the questionnaire survey. All the participants provided written informed consent prior to the survey.

To assess the self-protection awareness of these sanitation workers, they were further divided into 2 groups according to their age: young group (less than 45 years old) and aged group (older than 45 years old).

\section{Physical examination}

The physical examination for the occurrence of dermatoses focused on face, neck, arms, hands, and feet, skin areas typically exposed in their occupational envi- ronment. The presence or absence of the disease, the severity of illness and the personal history of skin diseases were recorded, especially specific occupational skin diseases.

\section{Questionnaires}

The interview questionnaire was self-designed by professional dermatologists. The first part of the questionnaire was demographic information of the participants, including gender, age, education background, length of service (year), individual monthly income (RMB), job type (formal or informal, off-the books) and resident characteristics (urban resident or rural migrant resident). The second part of the questionnaire evaluated health status of the participants, including personal history of environmental exposure diseases (such as dermatitis aestivale, prickly heat, frostbite, chap, varicosity, allergic dermatitis and hair loss), physical and mental health. The third part of the questionnaire assessed the responses of these sanitation workers to occupational protection measures, pre-job training, supply and use of protective equipments such as fluorescent clothes, gloves, soap, hand sanitizer and masks.

\section{Data analysis}

Statistical analysis was conducted with SPSS 11.0 (SPSS Inc., Chicago, IL). T-tests or the chi-square test were performed to compare the differences between groups, $\mathrm{p}<0.05$ was considered as statistically significant.

\section{Results}

\section{Demographic characteristics of participants}

Out of the 294 targeted sanitation workers, 21 (7.1\%) declined to participate in the survey. A total of 273 $(92.9 \%)$ questionnaires from the sanitation workers were completed, with 35 male $(12.8 \%)$ and 238 female $(87.2 \%)$. The mean age was $49.7 \pm 3.9$ years (range from $25-68) ; 38.5 \%$ of them were uneducated; $92.3 \%$ had a salary of only $1000 \mathrm{RMB}$ per month; $79.5 \%$ were rural migrant resident; 92.3\% were informal workers. 113 questionnaires from administrative staff were also obtained as control group, and the gender distribution was similar in both groups. The detailed information was shown in Table 1. 


\begin{tabular}{|c|c|c|c|c|}
\hline & \multicolumn{2}{|c|}{ Sanitation workers $(\mathrm{n}=273)$} & \multicolumn{2}{|c|}{ Administrative staff ( $\mathrm{n}=113$ ) } \\
\hline & Number & $\%$ & Number & $\%$ \\
\hline \multicolumn{5}{|l|}{ Gender } \\
\hline Male & 35 & 12.8 & 15 & 13.3 \\
\hline Female & 238 & 87.2 & 98 & 86.7 \\
\hline \multicolumn{5}{|l|}{ Years of age } \\
\hline $20 \sim 29$ & 7 & 2.6 & 4 & 3.5 \\
\hline $30 \sim 39$ & 21 & 7.7 & 11 & 9.7 \\
\hline $40 \sim 49$ & 98 & 35.9 & 52 & 46 \\
\hline $50 \sim 59$ & 119 & 43.6 & 46 & 40.7 \\
\hline $60 \sim 69$ & 28 & 10.3 & 0 & 0 \\
\hline \multicolumn{5}{|l|}{ Length of service (year) } \\
\hline$<5$ & 84 & 30.8 & 11 & 9.7 \\
\hline $5 \sim 9$ & 84 & 30.8 & 23 & 20.4 \\
\hline $10 \sim 19$ & 77 & 28.2 & 47 & 41.6 \\
\hline $20 \sim 29$ & 28 & 10.2 & 32 & 28.3 \\
\hline \multicolumn{5}{|l|}{ Education level } \\
\hline illiteracy & 105 & 38.5 & 0 & 0 \\
\hline primary school & 56 & 20.5 & 3 & 2.6 \\
\hline middle school & 91 & 33.3 & 35 & 31 \\
\hline high school & 21 & 7.7 & 47 & 41.6 \\
\hline undergraduate & 0 & 0 & 28 & 24.8 \\
\hline \multicolumn{5}{|c|}{ Individual monthly income $00(\mathrm{RMB})$} \\
\hline$<1000$ & 252 & 92.3 & 0 & 0 \\
\hline $1000 \sim 2000$ & 21 & 7.7 & 0 & 0 \\
\hline$>2000$ & 0 & 0 & 113 & 100 \\
\hline \multicolumn{5}{|l|}{ Job type } \\
\hline informal, off-the-books & 252 & 92.3 & 0 & 0 \\
\hline formal & 21 & 7.7 & 113 & 100 \\
\hline \multicolumn{5}{|l|}{ Resident characteristics } \\
\hline urban resident & 56 & 20.5 & 113 & 100 \\
\hline rural migrant resident & 217 & 79.5 & 0 & 0 \\
\hline
\end{tabular}

\section{Physical examination of dermatoses}

Hair loss (Figure 1A) and facial skin photo aging were compared between sanitation workers and administrative staff (Table 2). Symptoms of facial skin photo aging included oily, coarse pores (Figure 1B), pigmen- tation spots (Figure 1C), telangiectasia (Figure 1D), verruca senilis and deep wrinkles. Compared with control group (administrative staff), there was a relative higher rate of large pores, pigmentation spots, telangiectasia, senile wart, deep wrinkle and hair loss $(\mathrm{P}<0.05)$ in sanitation workers. 
Figure 1. Occupational health disease of sanitation workers. A: hair loss; B: coarse pores; C: pigmentation spots; D: telangiectasia; E: dermatitis aestivale.

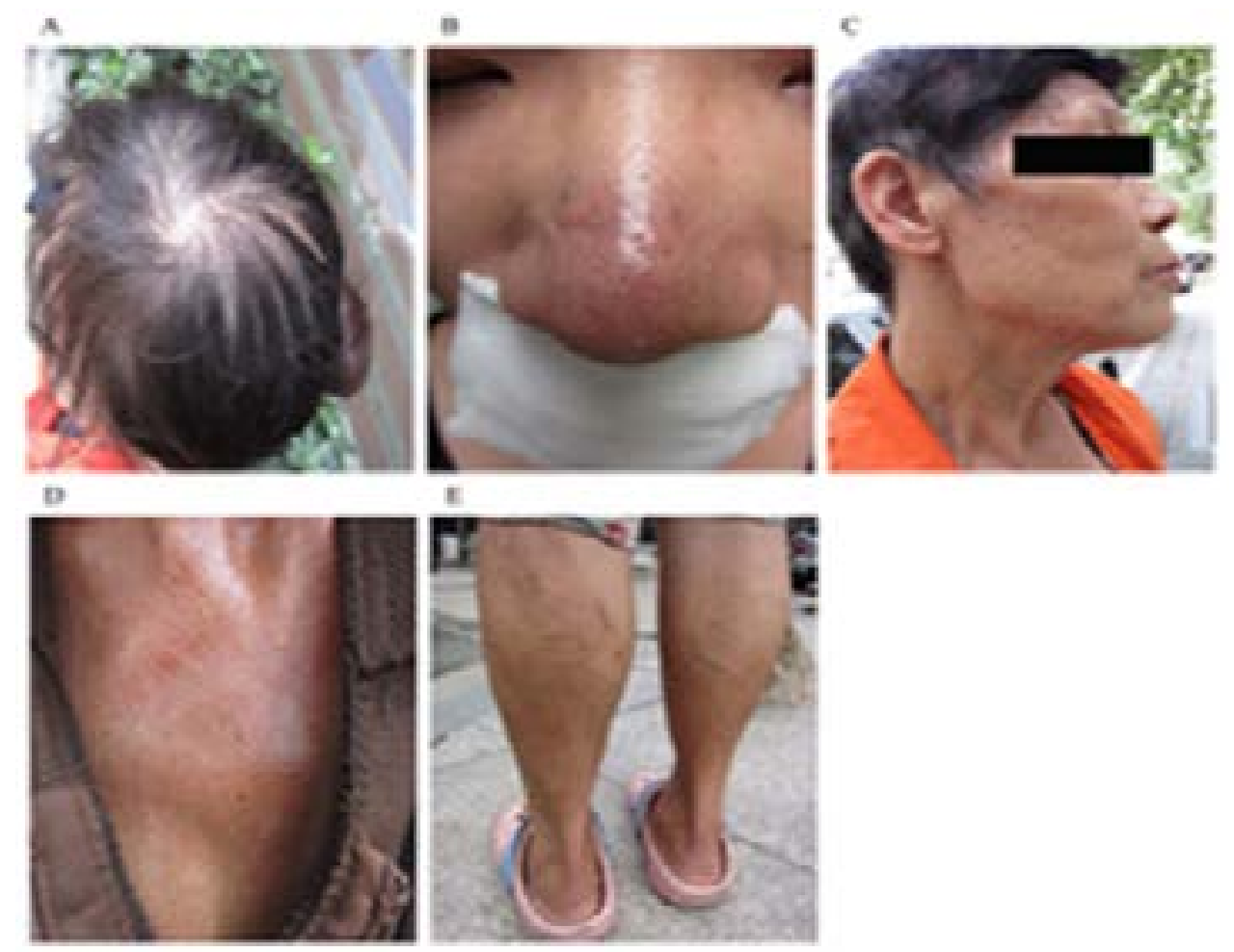

Table 2 Comparison of facial photo aging between sanitation workers and control group (administrative staff)

\begin{tabular}{|c|c|c|c|c|c|c|c|}
\hline Group & $\begin{array}{l}\text { Total } \\
\text { (n) }\end{array}$ & $\begin{array}{l}\text { Large pores } \\
(\%)\end{array}$ & $\begin{array}{c}\text { Pigmentation spots } \\
(\%)\end{array}$ & $\begin{array}{c}\text { Telangiectasia } \\
(\%)\end{array}$ & $\begin{array}{c}\text { Senile wart } \\
(\%)\end{array}$ & $\begin{array}{c}\text { Deep wrinkle } \\
(\%)\end{array}$ & $\begin{array}{l}\text { Hair loss } \\
\quad(\%)\end{array}$ \\
\hline $\begin{array}{l}\text { Sanitary } \\
\text { workers }\end{array}$ & 273 & $98(56.6)^{*}$ & $77(28.2)^{*}$ & $147(53.8)^{*}$ & $14(0.05)^{*}$ & $170(62.3)^{*}$ & $94(34.4)^{*}$ \\
\hline $\begin{array}{l}\text { Control } \\
\text { group }\end{array}$ & 113 & $22(19.5)$ & 27 (23.9) & $30(26.5)$ & $2(0.018)$ & $30(26.5)$ & $17(15)$ \\
\hline
\end{tabular}

${ }^{*} \mathrm{P}<0.05$ compared with control group.

\section{History of skin disease}

History of occupational health problems, such as dermatitis aestivale (Figure 1E), prickly heat, frostbite, chap, varicosity and allergic dermatitis were listed in
Table 3. Compared with control group, the sanitation workers had a higher rate of dermatitis aestivale, prickly heat, frostbite, rhagadia, varicosity, rhinallergosis and hair loss $(\mathrm{P}<0.05)$. 
Table 3 Comparison of disease history between sanitary workers and control group (administrative staff).

\begin{tabular}{cccccccc}
\hline Group (n) & $\begin{array}{c}\text { Dermatitis } \\
\text { aestivale } \\
(\%)\end{array}$ & $\begin{array}{c}\text { Prickly heat } \\
(\%)\end{array}$ & Frostbite (\%) & Rhagadia (\%) & $\begin{array}{c}\text { Varicosity } \\
(\%)\end{array}$ & Rhinallergosis (c. & $\begin{array}{c}\text { Hair loss } \\
(\%)\end{array}$ \\
$\begin{array}{c}\text { Sanitary } \\
\text { workers }\end{array}$ & $70(25.6)^{*}$ & $42(15.4)^{*}$ & $147(53.8)^{*}$ & $141(51.6)^{*}$ & $42(15.4)^{*}$ & $35(12.8)^{*}$ & $91(33.3)^{*}$ \\
$\begin{array}{c}\text { Control } \\
\text { group }\end{array}$ & $9(8)$ & $6(5.3)$ & $12(10.6)$ & $22(19.5)$ & $6(5.3)$ & $5(4.4)$ & $17(20.7)$ \\
\hline
\end{tabular}

${ }^{*} \mathrm{P}<0.05$, compared with control group.

\section{Supply and use of protective equipments}

Gloves, broadbrim and long-sleeved clothes were supplied by sanitation department of the city; anti-freezing cream was also supplied in winter. Most workers in young group used these protections in the routine work, while in aged group less people used them (Table 4 and 5). Young workers used protective measures significantly more than aged workers, such as sunglasses, sunscreen and other protective equipments $(77.8 \%$ vs. $63.3 \%, 55.6 \%$ vs. $36.7 \%, 98.4 \%$ vs. $63.3 \%$, respectively). $6.7 \%$ of aged workers never used the protective equipments. But aged workers knew more about the occupational hazard on eyes than young workers $(70 \%$ vs. $55.6 \%$ ), which was possibly because of the experiences of occupational eye diseases.

Table 4 Assessment of self-protection against UV among sanitation workers

\begin{tabular}{|c|c|c|c|c|c|c|c|c|c|c|}
\hline \multirow{2}{*}{$\begin{array}{c}\text { Age } \\
\text { (years) }\end{array}$} & \multirow{2}{*}{ No. } & \multirow{2}{*}{$\begin{array}{l}\text { Knowledge } \\
\text { of UV } \\
\text { n }(\%)\end{array}$} & \multicolumn{3}{|c|}{$\begin{array}{l}\text { Adverse effect of UV n } \\
(\%)\end{array}$} & \multicolumn{2}{|c|}{$\begin{array}{c}\text { Knowledge of protection } \\
\text { n }(\%)\end{array}$} & \multicolumn{3}{|c|}{$\begin{array}{l}\text { Use of protective equipments } \\
\qquad \mathrm{n}(\%)\end{array}$} \\
\hline & & & Skin & Eye & Hair & Sunglasses & Sunscreen & Frequent & Occasional & Never \\
\hline$<45$ & 63 & 49 (77.8) & $\begin{array}{c}56 \\
(88.9)\end{array}$ & $\begin{array}{c}35 \\
(55.6)\end{array}$ & $\begin{array}{c}21 \\
(33.3)\end{array}$ & 49 (77.8) & $35(55.6)$ & $\begin{array}{c}62 \\
(98.4)\end{array}$ & $1(0.6)$ & 0 \\
\hline$\geq 45$ & 210 & $\begin{array}{c}154 \\
(73.3 \%)\end{array}$ & $\begin{array}{c}148 \\
(70.5)^{*}\end{array}$ & $\begin{array}{c}147 \\
(70)^{*}\end{array}$ & $\begin{array}{c}63 \\
(30)\end{array}$ & $133(63.3)^{*}$ & $77 \underset{*}{(36.7)}$ & $\begin{array}{c}133 \\
(63.3)^{*}\end{array}$ & $84(40)^{*}$ & $14(6.7)^{*}$ \\
\hline
\end{tabular}

${ }^{*} \mathrm{P}<0.05$.

Table 5 Assessment of self-protection against frostbite and rhagadia among sanitation workers

\begin{tabular}{ccccccc}
\hline $\begin{array}{c}\text { Age } \\
\text { (years) }\end{array}$ & No. & \multicolumn{2}{c}{ Knowledge n (\%) } & Protection behavior n (\%) & $\begin{array}{c}\text { Enhancement of protect } \\
\text { awareness n (\%) }\end{array}$ \\
\cline { 2 - 5 } & & $\begin{array}{c}\text { preventing } \\
\text { frostbite }\end{array}$ & $\begin{array}{c}\text { preventing } \\
\text { rhagadia }\end{array}$ & $\begin{array}{c}\text { preventing } \\
\text { frostbite }\end{array}$ & $\begin{array}{c}\text { preventing } \\
\text { rhagadia }\end{array}$ & \\
\hline$<45$ & 63 & $57(90.5)$ & $28(44.4)$ & $35(55.6)$ & $56(88.9)$ & $56(88.9)$ \\
$\geq 45$ & 210 & $154(73.3 \%)^{*}$ & $84(40)^{*}$ & $112(53.3)$ & $168(80.0)$ & $84(40)^{*}$ \\
\hline
\end{tabular}

${ }^{*} \mathrm{P}<0.05$. 
For preventing frostbite and rhagadia, $80 \%$ workers knew how to prevent rhagadia and $53.8 \%$ knew measures against frostbite, there was no difference between the two groups. However, more workers in young group realized the availability of gloves and creams against rhagadia than aged workers ( $90.5 \%$ vs. $73.3 \%$ ). Young workers learned more via this survey and would pay more attention to self-protection compared to aged workers $(88.9 \%$ vs. $40 \%)$.

\section{Protective measurement against Ultra Violet light(UV)damage}

Our study demonstrated that most workers (74.4\%) were conscious of the damage of UV; many of them $(74.7 \%)$ knew the harmful effect of UV on skin, while less of them knew the side effects of UV on hair $(30.8 \%)$. There was no significant difference of the knowledge of UV among workers in different age groups.

More workers in young group knew the protective effect of sunglasses and sunscreen than aged group ( $77.8 \%$ vs. $63.3 \%, 55.6 \%$ vs. $36.7 \%$, respectively), and young group used protective equipments more often than aged group ( $98.4 \%$ vs. $63.3 \%$ ). Results were shown in Table 4.

\section{Protection against frostbite and rhagadia}

As shown in Table 5, the proportion of sanitation workers who used self-protective equipments against frostbite and rhagadia were $53.8 \%$ and $82.1 \%$ respectively. There was no significant difference between young workers and the aged, but more workers in young group knew regular protection against frostbite than that in aged group $(90.5 \%$ vs. $73.3 \%)$. This survey might enhance their protection behavior $(88.9 \%$ vs. $40 \%$, respectively).

\section{Discussion}

Sanitation workers in the city clean the streets perennially, whether in hot summer or cold winter.Years of exposure to the UV, heat, cold, wind, sand, dust and long periods standing lead to kinds of health problems. Previous researches reported that musculoskeletal disorders (periarthritis of shoulder, cervical spondylopathy, arthritis, and so on $)^{6,9}$ and respiratory symptoms (chronic bronchitis) ${ }^{4,10-12}$ were common diseases in sanitation workers. In the survey carried out by Liang et al, they performed a comparison of the respiratory function between sanitation workers and teachers, the results showed that the respiratory function of sanitation workers significantly decreased after ten years' work, which was related to the service time ${ }^{13}$. The incident rate of chronic bronchitis among sanitation workers was also higher than that of the control group in a survey carried out in India ${ }^{4}$. Another survey showed that the prevalence of spinal disease increased with age, and the incidence of chronic disease was much higher in sanitation workers than other people ${ }^{14}$. Nayak et al. reported dermatological problems of street sanitation workers in India and gave some recommendations on improving their health status. ${ }^{2}$.

From the demographic characteristics in this study, we could find that most sanitation workers were female, rural migrant residents with a low level of education. According to the statistics, the age of most workers $(79.5 \%)$ were among 40 to 60 years old; most workers were rural migrant resident $(79.5 \%) ; 38.7 \%$ of them received no formal education, $7.7 \%$ received a high school diploma which was the highest diploma among all workers; most workers were informal (92.3\%), with a relative low month salary (1000 RMB). The characteristics of sanitation workers were summarized as follows: old-age, rural migrant resident, informal workers with limited education and low income. Their dwelling environment, diet nutrition and working environment were also poor.

Sanitation workers were often exposed to a variety of work-related hazards such as sun exposure, cold air, dirt, infective organisms, chemicals, animal excreta, and sharp objects ${ }^{2}$, which would induce dermatological problems in their face, hands, feet and the rest exposed skin of the body.

UV damage was the most common problems. In humans, excessive exposure to UV radiation can result in chronic harmful effects on the skin, eye and immune system $^{15}$. Overexposure to UV radiation can not only cause sunburn and pigmentation but also some forms of skin cancer due to the direct damage of DNA by ultraviolet. Besides, UV radiation damages collagen fibers, accelerates aging of the skin and leads to deep wrinkles in the skin. Both UVA and UVB destroy vitamin $A$ in skin, which may cause further damage ${ }^{16}$. The eye is most sensitive to UV, exposure of the eye to UV may cause welder's flash or arc eye (photokeratitis) and 
can lead to cataracts, pterygium and pinguecula forma$\operatorname{tion}^{17,18}$. To a lesser extent, UVB in sunlight also causes photokeratitis ("snow blindness"), and the cornea, the lens and the retina can be damaged. In our study, there was no skin cancer found among these sanitation workers. However, compared with control group, they had a much higher rate of photo aging, such as pigmentation and deep wrinkles in the skin. Other dermal conditions caused by UV exposure included oily skin, coarse pores, telangiectasia, verruca senilis and hair loss. Considering the increased risk of UV exposure, the wide-brim hats, masks and protective eye wear are recommended to use for full-coverage of skin and eye protection.

Besides skin photo aging caused mainly by UV exposure, many other dermatoses of sanitation workers can be connected with their working conditions. Prickly heat and dermatitis aestivale were mainly caused by the high temperature; frostbite and chap could take place when skin suffered wind and cold; allergic dermatitis were caused by contact with pathogens, dust or other hazardous materials; long periods standing and heavy manual work led to varicosity.

Poor working conditions such as the long working hours, large cleaning scope, high working intensity and poor environment, caused increasing health and safety issues during the sanitation work ${ }^{6,19}$. Workers and employers were both aware of the occupational and environmental health hazards. But on account of the absence of the specific protective policy for these informal workers and the lack of permanent work places, it is difficult to guarantee the occupational health and safety of these sanitation workers ${ }^{20}$. Our investigation would help to direct policy decisions aimed at reducing the risks of occupational diseases and improving the safety and health of sanitation workers, especially these informal workers.

To our knowledge, this is the most comprehensive investigation on the association between environment and the risks of occupational diseases among sanitation workers. These occupational health problems can be prevented through engineering, medical and legislative measures. Job training and personal protective equipments should be more supplied in larger numbers by local government and relevant organizations.

\section{Reference}

1. Chandler, T.D. and P. Feuille, Cities, unions, and the privatization of sanitation services. Journal of Labor Research, 1994. 15(1): p. 53-71.

2. Nayak, S., et al., Dermatologic evaluation of street sanitation workers. Indian J Dermatol, 2013. 58(3): p. 246. 3. Md Khudzari, J., et al., Screening heavy metals levels in hair of sanitation workers by X-ray fluorescence analysis. J Environ Radioact, 2013. 115: p. 1-5.

4. Sabde, Y.D. and S.P. Zodpey, A Study of Morbidity Pattern in Street Sweepers: A Cross-sectional Study. Indian J Community Med, 2008. 33(4): p. 224-8.

5. Huerta-Franco, M.R., et al., Effects of occupational stress on the gastrointestinal tract. World J Gastrointest Pathophysiol, 2013. 4(4): p. 108-118.

6. Tiwari, R.R., Occupational health hazards in sewage and sanitary workers. Indian J Occup Environ Med, 2008. 12(3): p. 112-5.

7. Schmidt, S.L. and K.R. Flaherty, Clinical year in review I:interstitial lung disease, occupational and environmental lung disease, education of residents and fellows, and pediatrics. Proc Am Thorac Soc, 2011. 8(5): p. 389-97.

8. Omland, O., et al., Occupational chronic obstructive pulmonary disease: a systematic literature review. Scand J Work Environ Health, 2014. 40(1): p. 19-35.

9. JM, S., Encyclopaedia of occupational health and safety. International Labour Organization, 1998. 1.

10. Rylander, R., Health effects among workers in sewage treatment plants. Occup Environ Med, 1999. 56(5): p. 354-357.

11. Thorn J, B.L., Rylander R, Work related symptoms among sewage workers: a nationwide survey in Sweden. Occup Environ Med, 2002. 59(8): p. 562-566.

12. Zuskin, E., J. Mustajbegovic, and E.N. Schachter, Respiratory function in sewage workers. Am J Ind Med, 1993. 23(5): p. 751-61.

13. LW Liang, S.L., LH Huang, YF Wan, LF Yang, RY $\mathrm{Xu}, \mathrm{A}$ follow-up study on pulmonary function in urban sanitary workers. Chinese Journal of Industrial Medicine, 2000. 13(2): p. 93-95.

14. JC Yu, X.Z., XX Yin, ZS Hu, S Zhu, ZL Huang, Y Liang, Study on the health status and social welfare of the sanitary workers in central districts of Wuhan. Medicine and Society, 2010. 3: p. 7-8.

15. Young, A.R. and S.L. Walker, UV radiation, vitamin $\mathrm{D}$ and human health: an unfolding controversy introduction. Photochem Photobiol, 2005. 81(6): p. 1243-5. 
16. Berne, B., et al., UV treatment of uraemic pruritus reduces the vitamin A content of the skin. Eur J Clin Invest, 1984. 14(3): p. 203-6.

17. Nolan, T.M., et al., The role of ultraviolet irradiation and heparin-binding epidermal growth factor-like growth factor in the pathogenesis of pterygium. $\mathrm{Am} \mathrm{J}$ Pathol, 2003. 162(2): p. 567-74.

18. Di Girolamo, N., M. Coroneo, and D. Wakefield, Epidermal growth factor receptor signaling is partially responsible for the increased matrix metalloprotein- ase-1 expression in ocular epithelial cells after UVB radiation. Am J Pathol, 2005. 167(2): p. 489-503.

19. Fahim, A.E. and M. El-Prince, Passive smoking, pulmonary function and bronchial hyper-responsiveness among indoor sanitary workers. Ind Health, 2012. 50(6): p. 516-20.

20. Yu, G.P., C.C. Hsieh, and J. Peng, Risk factors associated with the prevalence of pulmonary tuberculosis among sanitary workers in Shanghai. Tubercle, 1988. 69(2): p. 105-12. 